\title{
Human rights violations in medicine: a-to-z action guide by Dr. Pamela Wible
}

\author{
Erin Nissen Castelloe \\ Private Pharmaceutical Medicine Consultant, San Diego, CA, USA
}

\begin{abstract}
To organize work in such a manner that it becomes meaningless, boring, stultifying, or nerve-racking for the worker would be little short of criminal; it would indicate a greater concern with goods than with people, an evil lack of compassion and a soul-destroying degree of attachment to the most primitive side of this worldly existence.

E. F. Schumacher, Small Is Beautiful: Economics as if People Mattered
\end{abstract}

And don't make the mistake of calling us resilient. To not have been destroyed, to not have given up, to have survived, is no badge of honor. Would you call an attempted murder victim resilient? Tommy Orange, There There

Correspondence: Erin Nissen Castelloe, Private Pharmaceutical Medicine Consultant, 12594 Kestrel Street, 92129 San Diego, CA, USA.

Tel: +1.858 .3546441 .

E-mail: erin.castelloe@gmail.com

Acknowledgments: Dr. Castelloe extends heartfelt thanks to Dr. Wible and the editorial staff of Qualitative Research in Medicine \& Healthcare for this opportunity to join the conversation about medical student and physician mental health.

Contributions: Erin Nissen Castelloe wrote and submitted this review of the book Human rights violations in medicine: a-to-z action guide by Dr. Pamela Wible.

Key words: Wible; system-induced distress; burnout; physician mental health; physician suicide.

Received for publication: 21 October 2019

Accepted for publication: 25 October 2019.

This work is licensed under a Creative Commons Attribution NonCommercial 4.0 License (CC BY-NC 4.0).

${ }^{\circ}$ Copyright: the Author(s), 2019

Licensee PAGEPress, Italy

Qualitative Research in Medicine \& Healthcare 2019; 3:139-140

doi:10.4081/qrmh.2019.8635
Dr. Pamela Wible's latest book, Human Rights Violations in Medicine: A-to-Z Action Guide, expands upon her ground-breaking work in physician and medical student suicide prevention, ${ }^{1-4}$ elucidating the systematically normalized circumstances that erode physician and medical student mental health. In it, Wible details a step-by-step guide to:

1. Reframing the abuses heaped upon physicians and medical students as violations of innate human rights;

2. Labeling each violation in clear and concise language;

3. Documenting each violation in a fastidious manner that supports legal action, should it be required;

4. Reporting each violation to the appropriate personnel in order to deter further violations and safe-guard against retaliation; and

5. Supporting those who have suffered violations so they may heal and continue their vital work in the medical profession.

The cover of the book lists some of the most common human rights violations in medicine: food and water deprivation, punishment when sick, sleep deprivation, bullying, pimping, harassment, racism, violence, and sexism. Reading those words on the cover made me cringe and swallow hard. Suddenly, I heard echoes from my years in training and practice. This is just the way it is. If we don't toughen you up, you'll never survive in this career. Suck it up. Do you know how many people would kill to be where you are? If you can 't hack it, there's the door. Even years after the fact, those voices linger. Had I received Dr. Wible's advice during my years in medical school, residency, or medical practice, my personal experience with human rights violations in medicine - née burnout, ${ }^{5,6}$ née system-induced distress ${ }^{7}$ - might have ended differently. Perhaps it still can.

Wible's book and her mission fill me with hope: hope that we can eradicate human rights violations from this career that I love; hope that we can direct the compassionate care we show our patients toward medical students, residents, physician colleagues, and ourselves; and hope that we can shatter the stigma surrounding mental health diagnoses and prioritize mental healthcare for all. Join me in hope. Join me in recommending Human Rights Violations in Medicine: A-to-Z Action Guide, The Ultimate Manual for Physician \& Medical Student Self-Defense. 


\section{References}

1. Wible P. Human rights violations in medicine. A-to-Z action guide. Pamela Wible, M.D. 2019.

2. Wible P. Physician suicide letters. Pamela Wible MD 2017.

3. Wible P. What I've learned from my tally of 757 doctor suicides. The Washington Post 2018. Available from: https://www.washingtonpost.com/national/healthscience/what-ive-learned-from-my-tally-of-757-doctor-suicides/2018/01/12/b0ea9126-eb50-11e7-9f92-10a2203f6c8d story.html Accessed: October 2019.

4. Wible P. Frank H Netter MD School of Medicine Com- mencement 2019. Pamela Wible, MD 2019 Available from: https://www.idealmedicalcare.org/ Accessed: October 2019.

5. Castelloe E. Finding myself in medicine. QRMH 2017;1:15. Available from: https://www.pagepressjournals.org/index. php/qrmh/article/view/6301 Accessed: October 2019.

6. Castelloe E. Tincture of time. QRMH 2017;1:103-8. Available from: https://www.pagepressjournals.org/index.php/ qrmh/article/view/6925 Accessed: October 2019.

7. Winner J, Knight C. Beyond burnout: addressing system-induced distress. Fam Pract Manage 2019;26:4-7. Available from: https://www.aafp.org/fpm/2019/0900/p4.html Accessed: October 2019. 